\title{
PROFIL HERPES ZOSTER DI POLIKLINIK KULIT DAN KELAMIN RSUP PROF. DR. R. D. KANDOU MANADO PERIODE JANUARI - DESEMBER 2012
}

\author{
${ }^{1}$ Sahriani HR \\ ${ }^{2}$ Marlyn G. Kapantow \\ ${ }^{2}$ Herry E. J. Pandaleke
}

\author{
${ }^{1}$ Kandidat Skripsi Fakultas Kedokteran Universitas Sam Ratulangi Manado \\ ${ }^{2}$ Bagian Kulit dan Kelamin Fakultas Kedokteran Universitas Sam Ratulangi Manado \\ Email: sahrianihr10110@yahoo.co.id
}

\begin{abstract}
Background - Herpes zoster that is also called with shingles, dampa, or cacar ular is a disease caused by the infection of varicella zoster virus (VZV) and affects the skin and mucosa. This infection is a virus reactivation after primer infection characterized with unilateral radicular pain and vesicular lesion that manifests on the skin and its innervation.

Objctive - The aim of this research is to find out the profile of outpatient diagnosed with herpes zoster in Dermatovenereology Department RSUP Prof. DR. R. D. Kandou Manado from January to December 2012.

Methods - It is a retrospective study that describe several factors related to the subjects, using medical records data from January to December 2012. There were 22 patients evaluated.

Result - 2\% of 1096 new patients in the period of January to December 2012 were diagnosed as herpes zoster. $73 \%$ were 45 - 64 years old, with $54,5 \%$ men and $45,4 \%$ women, oftalmicus nerve involved counted to $32 \%$, the most common therapy were the combination of Antivirus + Analgesic + Neurovitamin (36,3\%).

Conclusion - Increasing of the age could be the factor to reactivate the viral infection. The incidence were not affected by sex. Antivirus remain the drug of choice to treat herpes zoster.
\end{abstract}

Key words : herpes zoster - reactivation - virus

\section{Abstrak}

Latar Belakang - Herpes zoster atau disebut juga dengan shingles, dampa, cacar ular adalah penyakit yang disebabkan oleh infeksi virus varisela - zoster (VVZ) yang menyerang kulit dan mukosa. Infeksi ini merupakan reaktivasi virus yang terjadi setelah infeksi primer yang ditandai dengan adanya nyeri radikuler unilateral serta timbulnya lesi vesikuler yang terbatas pada dermatom yang dipersarafi.

Tujuan Penelitian - Mengetahui profil herpes zoster di poliklinik Kulit dan Kelamin RSUP Prof. Dr. R. D. Kandou Manado periode Januari - Desember 2012.

Metode - Penelitian ini bersifat deskriptif retrospektif, yaitu mendeskripsikan beberapa faktor yang berhubungan dengan subjek penelitian yang ada. Data penelitian diambil dari rekam medik periode Januari - Desember 2012. Jumlah sampel penelitian sebanyak 22 orang. 
Hasil Penelitian - Terdapat 2\% penderita herpes zoter dari 1096 pasien periode Januari Desember 2012. Pada umur 45 - 64 tahun terdapat 73\% penderita, laki - laki 54,5\% dan perempuan $45,5 \%$, lokasi yang sering terkena adalah oftalmikus $32 \%$, serta kombinasi terapi yang sering digunakan adalah Antivirus + Analgesik + Neuronvitamin 36,3\%.

Kesimpulan - Peningkatan usia dapat memicu reaktivasi virus. Kejadian herpes zoster tidak dipengaruhi oleh jenis kelamin. Obat yang sering digunakan adalah antivirus.

Kata kunci : herpes zoster - reaktivasi - virus

\section{PENDAHULUAN}

Herpes zoster adalah penyakit yang disebabkan oleh infeksi virus varisela - zoster (VVZ) yang menyerang kulit dan mukosa, infeksi ini merupakan reaktivasi virus yang terjadi setelah infeksi primer. ${ }^{1}$ Infeksi primer dengan virus varisela zoster menimbulkan varisela (cacar air). Virus membentuk infeksi laten di ganglia dorsal sehingga menyebabkan terjadinya herpes zoster. ${ }^{2}$

Virus varisela zoster merupakan rantai ganda DNA yang termasuk dalam anggota famili virus herpes yang tergolong virus neuropatik atau neurodermatotropik. Reaktivasi virus varisela zoster dapat dipicu oleh berbagai faktor seperti antara lain pembedahan, penyinaran, lanjut usia, dan keadaan tubuh yang lemah meliputi malnutrisi, seseorang yang dalam pengobatan imunosupresan jangka panjang, atau menderita penyakit sistemik. ${ }^{3-5}$

Orang yang pernah menderita varisela dapat terkena penularan herpes zoster yang dapat ditularkan melalui kontak langsung dengan lesi aktif penderita herpes zoster. Selain itu, penularan juga bisa melalui sekresi pernapasan pada individu imunokompromais dari pasien herpes zoster aktif. ${ }^{6}$

Di Amerika, herpes zoster jarang pada anak - anak, dimana lebih dari 66\% mengenai usia diatas 50 tahun, kurang dari 10\% mengenai usia dibawah 20 tahun dan 5\% mengenai usia kurang dari 15 tahun. $^{7}$

Dari hasil penelitian deskriptif retrospektif di bagian polikklinik Kulit dan Kelamin RSU Prof. DR. R. D. Kandou Manado dari Januari 2001 Desember 2005 didapatkan 137 penderita dengan persentase penyakit herpes zoster sebesar 3,19\% dari total penderita rawat jalan. $^{8}$

Penatalaksanaan yang tepat pada infeksi virus varisela - zoster sangat penting karena akan menurunkan durasi lesi serta risiko komplikasi, misalnya Neuralgia Pascaherpetik. Penatalaksanaan infeksi varisela - zoster yang utama berupa pemberian antivirus, disertai dengan pemberian terapi simtomatis, berupa antiinflamasi, analgesik dan neuroaktif. Selain terapi pada infeksi pada varisela - zoster, perlu dilakukan pencegahan infeksi varisela - zoster dengan vaksinasi aktif yang akan menurunkan risiko infeksi yang berat pada individu risiko tinggi. ${ }^{9-11}$ 


\section{METODE PENELITIAN}

Penelitian ini bersifat deskriptif retrospektif, yaitu mendeskripsikan beberapa faktor dari subjek penelitian yang telah ada, dan secara retrospektif dengan menggunakan data subjek penelitian yang diambil dari catatan medik pasien Herpes Zoster di Poliklinik Kulit dan Kelamin RSUP Prof. DR. R. D. Kandou Manado periode Januari Desember 2012 yang dilaksanakan dari bulan November - Desember 2013. Populasi adalah seluruh data pasien yang baru berobat di Poliklinik Kulit dan Kelamin RSUP Prof. DR. R. D. Kandou Manado periode Januari - Desember 2012 dan sampel semua pasien baru yang didiagnosis dengan Herpes Zoster yang berobat di Poliklinik Kulit dan Kelamin RSUP Prof. DR. R. D. Kandou Manado periode Januari - Desember 2012. Variabel penelitian : umur, jenis kelamin, dermatom yang terkena (herpes zoster oftalmikus, herpes zoster fasialis, herpes zoster servikalis, herpes zoster torakalis, herpes zoster femoralis, herpes zoster abdominalis, herpes zoster lumbalis, herpes zoster generalisata), terapi.

Pengambilan data dilakukan dengan pengumpulan data secara deskriptif retrospektif dari status penderita herpes zoster yang baru pertama kali datang berobat yang tercatat pada buku register dibagian rekam medik yang ada di Poliklinik Kulit dan Kelamin RSUP Prof. DR. R. D. Kandou Manado periode Januari - Desember 2012.

\section{HASIL PENELITIAN}

Setelah dilakukan penelitian retrospektif di Bagian Rekam Medik dan di Poliklinik Kulit dan Kelamin RSUP Prof. DR. R. D. Kandou Manado dari bulan November - Desember 2013 telah diperoleh data dengan diagnosis herpes zoster sebagai berikut :

Tabel 1. Distribusi penderita Herpes Zoster periode Januari - Desember 2012

\begin{tabular}{ccc}
\hline $\begin{array}{c}\text { Jumlah } \\
\text { Penderita } \\
\text { Rawat Jalan }\end{array}$ & $\begin{array}{c}\text { Jumlah } \\
\text { Penderita } \\
\text { Herpes } \\
\text { Zoster }\end{array}$ & $\begin{array}{c}\text { Persentase } \\
(\%)\end{array}$ \\
\hline 1096 & 22 & 2 \\
\hline
\end{tabular}

Berdasarkan tabel di atas total penderita rawat jalan sepanjang tahun 2012 di Poliklinik Kulit dan Kelamin RSUP Prof. DR. R. D. Kandou Manado adalah 1096. Dari 1096 penderita tersebut terdapat 22 penderita dengan diagnosis herpes zoster dengan presentase $2 \%$.

Tabel 2. Distribusi Herpes Zoster berdasarkan umur

\begin{tabular}{ccc}
\hline $\begin{array}{c}\text { Interval } \\
\text { Umur (Thn) }\end{array}$ & Jumlah & $\begin{array}{c}\text { Presentase } \\
(\%)\end{array}$ \\
\hline$<1$ & 0 & 0 \\
$1-4$ & 0 & 0 \\
$5-14$ & 0 & 0 \\
$15-24$ & 1 & 4,5 \\
$25-44$ & 4 & 18 \\
$45-64$ & 16 & 73 \\
$\geq 65$ & 1 & 4,5 \\
\hline Total & 22 & $100 \%$ \\
\hline
\end{tabular}

Pada tabel 2. Dapat dilihat distribusi herpes zoster berdasarkan umur, di dapatkan jumlah penderita yang paling banyak pada kelompok umur 45 - 64 tahun sebanyak 16 orang (73\%), kemudian diikuti oleh kelompok umur 25 - 44 tahun sebanyak 4 orang (18\%). 
Tabel 3. Distribusi Herpes Zoster berdasarkan jenis kelamin

\begin{tabular}{ccc}
\hline Jenis Kelamin & Jumlah & $\begin{array}{c}\text { Persentase } \\
(\%)\end{array}$ \\
\hline Laki - Laki & 12 & 54,5 \\
Perempuan & 10 & 45,5 \\
\hline Total & 22 & $100 \%$ \\
\hline
\end{tabular}

Pada tabel 3. Distribusi herpes zoster berdasarkan jenis kelamin, dapat dilihat bahwa herpes zoster paling sering mengenai jenis kelamin laki - laki yaitu sebanyak 12 penderita dari 22 penderita dengan presentase $54,5 \%$, sedangkan pada perempuan terdapat 10 kasus dengan presentase $45,5 \%$.

Tabel 4. Distribusi Herpes Zoster berdasarkan lokasi yang terkena

\begin{tabular}{ccc}
\hline Lokasi & Jumlah & $\begin{array}{c}\text { Presentase } \\
(\%)\end{array}$ \\
\hline Oftalmikus & 7 & 32 \\
Fasialis & 2 & 9 \\
Servikalis & 3 & 13,7 \\
Torakalis & 6 & 27,3 \\
Femoralis & 2 & 9 \\
Abdominalis & 2 & 9 \\
Lumbalis & 0 & 0 \\
Generalisata & 0 & 0 \\
\hline Total & 22 & $100 \%$
\end{tabular}

Pada tabel 4 distribusi herpes zoster berdasarkan lokasi yang terkena, dapat dilihat bahwa lokasi yang sering terkena adalah oftalmikus dengan jumlah 7 (32\%) penderita, diikuti oleh torakalis $6(27,3 \%)$.
Tabel 5. Distribusi Herpes Zoster berdasarkan terapi yang diberikan

\begin{tabular}{lcc}
\hline \multicolumn{1}{c}{ Terapi } & $\begin{array}{c}\text { Jumlah } \\
\text { Prese - } \\
\text { ntase } \\
(\%)\end{array}$ \\
\hline Antivirus & 2 & 9 \\
Antivirus + Analgesik & 5 & 22,7 \\
Antivirus + Antibiotik & 2 & 9 \\
Antivirus + & 1 & 4,5 \\
$\begin{array}{l}\text { Neuronvitamin } \\
\text { Antivirus + Analgesik + } \\
\text { Antibiotik }\end{array}$ & 1 & 4,5 \\
$\begin{array}{l}\text { Antivirus + Analgesik + } \\
\text { Neuronvitamin } \\
\text { Antivirus + Analgesik + }\end{array}$ & 8 & 36,3 \\
$\begin{array}{l}\text { Antibiotik } \\
+ \text { Neuronvitamin }\end{array}$ & 3 & 14 \\
\hline \multicolumn{1}{c}{ Total } & 22 & $100 \%$ \\
\hline
\end{tabular}

Dari tabel 5. Distribusi herpes zoster berdasarkan terapi yang diberikan, dapat dilihat bahwa obat yang paling sering digunakan adalah Antivirus + Analgesik + Neuronvitamin sebanyak 8 orang (36,3\%), diikuti dengan Antivirus + Analgesik sebanyak 5 orang (22,7\%).

\section{PEMBAHASAN}

Pada penelitian ini didapatkan jumlah penderita herpes zoster sebanyak 22 (2 \%) penderita dari 1096 pasien yang datang berkunjung. Hal ini menunjukkan adanya peningkatan bila dibandingkan dengan penelitian retrospektif oleh Tangkuman YY di Poliklinik Kulit dan Kelamin RSUP Prof. DR. R. D. Kandou Manado periode Januari - Desember 2005 yaitu sebanyak 25 (0,61\%) penderita dari 4125 pasien yang datang berkunjung. ${ }^{8}$ Peningkatan ini menurut penulis mungkin disebabkan karena penderita tersebut mengalami kekurangan 
gizi (malnutrisi) serta dalam pengobatan imunosupresan jangka panjang.

Distribusi berdasarkan umur penderita herpes zoster banyak ditemukan pada kelompok umur 45 - 64 tahun yaitu sebanyak $73 \%$ penderita. Hal ini sesuai dengan kepustakaan yang mengatakan bahwa insiden meningkat sesuai dengan pertambahan usia. Pada usia lanjut terjadi penurunan imunitas seluler yang merupakan faktor utama penyebab reaktifasi. ${ }^{7}$ Sedangkan pada kelompok umur kurang dari 15 tahun tidak didapatkan penderita. Herpes zoster sangat jarang pada anak umur kurang dari 10 tahun kecuali pada mereka yang diberi terapi imunosupresi untuk keganasan atau penyakit lain (HIV). ${ }^{6}$

Distribusi berdasarkan jenis kelamin penderita herpes zoster ditemukan sebanyak 12 penderita laki laki dengan presentase 54,5 \% dan 10 penderita perempuan dengan presentase 45,4 \%. Penderita laki - laki lebih banyak daripada perempuan. Terdapat kepustakaan yang menyebutkan bahwa insiden herpes zoster adalah sama pada laki - laki dan perempuan., ${ }^{1,2}$

Lokasi lesi herpes zoster banyak ditemukan pada daerah oftalmikus (32\%) dari 22 penderita. Pada torakalis 27,3 \%, servikalis $13,7 \%$, fasialis, femoralis dan abdominalis $9 \%$, sedangkan lumbalis dan generalisata tidak terdapat penderita. Hal ini disebabkan karena kemungkinan penderita herpes zoster yang mengenai daerah oftalmikus langsung datang berobat ke RS untuk mendapatkan pengobatan dari dokter ahli, sehingga komplikasi pada mata dapat dicegah. Sedangkan pada herpes zoster yang mengenai daerah servikalis, torakalis, femoralis, abdominalis, dan lumbalis pada lokasi tersebut dapat ditangani oleh dokter umum di Puskesmas. Bila dibandingkan dengan penelitian retrospektif yang dilakukan oleh Tangkuman YY di Poliklinik Kulit dan Kelamin RSUP Prof. DR. R. D. Kandou Manado periode Januari - Desember 2005 lokasi lesi yang paling banyak ditemukan yaitu di daerah torakalis sebanyak 6 orang (24\%) dari 25 penderita. ${ }^{8}$

Distribusi berdasarkan terapi yang diberikan pada penderita herpes zoster didapatkan bahwa semua penderita menggunakan Antivirus, akan tetapi kombinasi yang banyak digunakan adalah Antivirus + Analgesik + Neuronvitamin yaitu sebanyak 8 orang (36,3\%) dari 22 penderita. Hal ini sesuai dengan kepustakaan yang mengatakan bahwa Antivirus adalah obat yang sering digunakan (asiklovir dan modifikasinya, misalnya valasiklovir dan famsiklovir).Asiklovir menjadi standar pengobatan herpes zoster. Pemberian antivirus dapat mengurangi lama sakit, keparahan dan waktu penyembuhan akan lebih singkat terutama bila diberikan sebelum 72 jam awitan lesi. Asiklovir bekerja sebagai inhibitor DNA polymerase pada virus.Analgesik diberikan untuk mengurangi neuralgia yang ditimbulkan oleh virus herpes zoster.Neuronvitamin diberikan untuk menjaga vitalitas dan pertumbuhan neuron dan Antibiotik diberikan untuk mencegah terjadinya infeksi sekunder. ${ }^{8}$

\section{KESIMPULAN}

Berdasarkan hasil penelitian di Bagian Rekam Medik dan di Poliklinik Kulit dan Kelamin RSUP Prof. Dr. R. D. Kandou Manado periode Januari Desember 2012, maka dapat diperoleh kesimpulan sebagai berikut : Angka 
kejadian herpes zoster di Poliklinik Kulit dan Kelamin RSUP Prof. DR. R. D. Kandou Manado dari bulan Januari Desember 2012 adalah 2\% penderita dari 1096 pasien rawat jalan. Kelompok umur terbanyak pada herpes zoster adalah pada kelompok umur 45 - 64 tahun, yaitu sebanyak 73\%.Herpes zoster banyak terdapat pada laki - laki yaitu 54,5\% penderita sedangkan pada perempuan terdapat $\quad 45,5 \%$ penderita.Daerah oftalmikus adalah lokasi lesi yang paling sering terkena herpes zoster dengan presentase 32 \%.Terapi yang paling sering digunakan adalah kombinasi antara Antivirus + Analgesik + Neuronvitamin yaitu sebanyak 36,3\% dari 22 orang penderita.

\section{SARAN}

Pada pengambilan data pasien disarankan agar status diisi dengan lengkap terutama dalam anamnesis dan pemeriksaan fisik untuk mendapatkan data yang akurat.Catatan medik sebaiknya disimpan di tempat tertentu sehingga dapat di gunakan pada penelitian selanjutnya.Perlunya peningkatan higiene dan sanitasi perorangan terlebih khusus pada usia lanjut, untuk mencegah timbulnya penyakit dan penurunan daya tahan tubuh.

\section{DAFTAR PUSTAKA}

1. Handoko RP. Penyakit virus. In: Djuanda A, ketua editor. Ilmu penyakit kulit dan kelamin. Edisi ke6. Jakarta: Fakultas Kedokteran Universitas Indonesia; 2011.h.110-28.

2. Arvin AM.Virus varisela-zoster. In: Wahab AS, editor. Ilmu kesehatan anak. Edisi 15. Volume 2. Jakarta: EGC.h.1097-100.

3. Price SA,Stawiski MA. Infeksi kulit. Patofisiologi. Edisi 6. Volume 2. Jakarta: EGC.h.1447.

4. Wicaksono D, Regar E, Rahmani NH. Modul Praktik Klinik Dermatovenereologi Fakultas Kedokteran Universitas Indonesia Rumah Sakit Umum Pusat Nasional Cipto Mangunkusumo. Jakarta: Mei 2013.

http://xa.yimg.com/kq/groups/865298 52/1660844164/name/Preskas_Herpes Zoster_Dwi_Evan_Hanifah.pdf.

5. Universitas Sumatra utara. Herpes zoster. Available from:

http://repository.usu.ac.id/bitstream/... /3/Chapter\%20II.pdf

6. Corwin EJ. Buku saku patofisiologi. Edisi 3 revisi. Jakarta: EGC.h.118 20

7. Lubis RD. Varisela dan herpes zoster. Departemen Kesehatan Kulit dan Kelamin Fakultas Kedokteran Universita Sumatera Utara. 2008. http//www.related:repository.usu.ac.id /bitstream/123456789/3425/1/08E008 95.pdf varicela dan herpes zoster pdf

8. Tangkuman YY. Profil Herpes Zosterdi polikklinik Kulit dan Kelamin RSU Prof. Dr. R.D. Kandou. Manado: Januari 2001 - Desember 2005.

9. Damayanti, Mustiastutik D, Heriwati DI, Nurharini F. Penatalaksanaan terkini infeksi varisela-zoster. Berkala ilmu Kesehatan Kulit dan Kelamin. Volume 21. Surabaya: 2 Agustus 2009.h.125-131.

10. Cunningham AL, Breuer J, Dwyer DE, Gronow DE, Helme RD, dkk.The prevention and management of herpes zoster. The medical journal 
of Autralia. Volume 188 Number 3. 4 Februari 2008.h.171-6.

https://www.mja.com.au/journal/.../p revention-and-management-herpespdf

11. Kane KSM, Lio PA, Stratigos AJ, Johnson RA. Color atlas \&synopsis of pediatric dermatology. Internasional edition.h.430-2

12. Kurniawan M, Dessy N, Tatang $M$. Varicela zoster pada anak. Universitas pelita harapan.

http://indonesia.digitaljournals.org/ind ex.php/medcin/article/download/83/8 8. 